\title{
Hate crimes and international institutions: A literature review
}

\author{
Corvinus University of Budapest, Budapest, Hungary \\ ORIGINAL RESEARCH PAPER \\ Received: September 24, 2020 • Accepted: December 20, 2020 \\ Published online: August 14, 2021 \\ (C) 2020 The Author(s)
}

ESZTER KIRS*

\begin{abstract}
The paper reflects on academic literature on the international normative and institutional framework related to hate crimes. Various theoretical and pragmatic issues have been discussed by academic authors, such as the challenges coming with the obligation of states to record hate crimes or to conduct efficient investigation, the limits of the potential impact of international review mechanisms, or the aims and content of resolutions adopted by international institutions and judgments delivered by the European Court of Human Rights. However, a wide range of practical and conceptual issues related to the existing international standards and the efficiency of international review mechanisms remain to be discussed in the academic sphere.
\end{abstract}

\section{KEYWORDS}

hate crimes, literature review, racist violence

\section{INTRODUCTION}

Bias motivated crimes, physical and verbal attacks targeting ethnic, national, religious or other social groups escalated in a number of European states in the 1990s that triggered dialogue and

\footnotetext{
*Corresponding author. E-mail: eszter.kirs@uni-corvinus.hu

The present paper was authored in the framework of the MTA-ELTE Lendület SPECTRA Research Group (Social prerequisites for the effective fight against bias-motivated crimes through criminal law and minority rights protection, contract number: LP2018-9/2018).
} 
action in the international organizations operating in the region. The European Parliament launched research on the phenomenon and made policy proposals; the European Commission against Racism and Intolerance issued recommendations and the drafting process of regulations on hate speech and hate crime within the framework of the EU, the Council of Europe and the OSCE was initiated by the 2000s. A growing number of applications have been submitted to the European Court of Human Rights in the last two decades that resulted in the elaboration of the standards by the Court related to efficient prosecution of hate crimes under the application of Article 14 of the European Convention. Academic literature has slowly followed the practice of international organizations in the area and has not covered numerous open questions related to the methods of the enforcement of relevant international legal norms or the impact of the projects run by international organizations.

\section{BROADER PERSPECTIVE: CONCEPTUAL AND PRAGMATIC CONCERNS RELATED TO THE EFFORTS OF INTERNATIONAL INSTITUTIONS}

From the early literature on bias motivated crimes in the context of the European regional organizations, the research of Paul Iganski ${ }^{1}$ reflected on the policy proposals and recommendations made by the European Parliament and the European Commission against Racism and Intolerance in the 1990s. The author aimed at the assessment of the legislative proposals submitted by the Kahn Commission in 1995. The Commission chaired by Jean Kahn, the President of the European Jewish Congress consisted of a representative from each of the Member States, two Members of the European Parliament, a representative from the Commission and an observer from the Council of Europe. The Kahn Commission emphasized the need to adopt binding European legislation combating racial discrimination and concluded that an essential precondition would be the amendment of the Treaty to insert a specific reference to combating racial discrimination. The operation of the Commission is considered as an important triggering factor in changing the political context and positions of EU Member States. ${ }^{2}$ Iganski discussed different aspects of racism and antisemitism, and among others, the review of the operation of racist organizations proposed by the Kahn Commission and the prohibition of incitement to racial hatred. The author raised fundamental concerns with regard to potential clashes between different human rights that can be resulted by the restrictive measures provided for by the normative framework proposed by the Commission or the ECRI.

As regards hate crimes, Iganski discussed the dilemma of whether the rights of the accused would be violated by criminal legal provisions on penalty enhancement or specific offences aimed at accounting for racist motivation. He shares his first impression that freedom of thought might be violated by the different qualification of and more severe sentencing in the case of offences committed out of bias motivation. By now, in the European region, there is a common understanding that stricter criminal legal approach is needed for the enhanced protection of the victim communities. However, the application of criminal law still raises various dilemmas while state authorities are weighing the interest of the victims for enhanced protection of their right

\footnotetext{
${ }^{1}$ Iganski (1999) 509-16.

${ }^{2}$ Directorate-General for Research (n.d.); Givens and Case (2014) 65-66.
} 
rooted in equal human dignity, and the fundamental rights of perpetrators or members of extremist organizations who might be impacted by the action of law enforcement agencies.

The second major concern outlined by Iganski is related to rules on the evidentiary procedure. He argues that the use of circumstantial evidence, when an explicit admission of the motivation is missing, is "troubling". He presented constitutional protection given in two domestic contexts, the US and the UK, and demonstrates that the domestic normative framework can provide for the necessary safeguards against the potential restriction of the rights of the accused. Iganski does not argue against the realization of the proposals made by the Kahn Commission or the ECRI but sheds light on potential clashes between the enhanced protection of equal human dignity through criminal legal measures and the procedural and other fundamental rights of the accused. He warns that a comparative transnational research should be done in order to adequately address these concerns. ${ }^{3}$ This kind of transnational research so far has been primarily done by the EU Fundamental Rights Agency and the OSCE ODIHR.

However, the impact of the activities of international organizations is obviously limited by the domestic context. Azra Junuzovic aimed at providing a brief and pragmatic summary of domestic prerequisites to the positive impact of international regulations and measures. ${ }^{4}$ The starting idea was that international organizations can support domestic stakeholders in their efforts to combat hate crimes and facilitate the exchange of best practices but a real change cannot be achieved without the genuine political will in the specific countries. Her pragmatic approach originates from her previous position as the Deputy Head of the Tolerance and Nondiscrimination Department of the OSCE ODIHR. After identifying the main characteristics of the operation of different organizations, ${ }^{5}$ she makes a strong statement that the implementation of any of the regulations or recommendations adopted by the international organizations cannot be deemed more than a "tick-off-the box" exercise. Another important message of the author is that the "comprehensive response to hate crimes is also a complex process of social change that requires legal and policy amendments as well as a change of mentality in which adequate response to hate crimes and protection of victims is placed at the forefront of public policy interventions". 6

Junuzovic, focusing on the impact of the operation of the ODIHR, discusses, in details, four factors that contribute to a broader and real impact of the international efforts under her understanding.

1. A specific hate crime case or series of incidents can draw the attention of the public and result in the pressure on the government to take action. She refers to the scandal broadly discussed in the media relating to the failure of the German investigative authorities to obtain evidence about three neo-Nazi individuals who killed ten people from 2000 to 2007. The German government established a special investigative commission as a result of the public outcry.

\footnotetext{
${ }^{3}$ Iganski (1999) 510-11.

${ }^{4}$ Junuzovic (2019).

${ }^{5}$ ODIHR as a "collection point" providing technical assistance, ECRI formulating recommendations, FRA publishing research papers and sharing opinions with EU institutions and Member States without mentioning the European Court of Human Rights as a judicial body since her analysis is aimed at outlining proposals related to the operation of international organizations.

${ }^{6}$ Junuzovic (2019) 263.
} 
2. The political aspirations of a national government for international reputation, such as in the case of Croatia whose Ministry of Foreign Affairs requested the assistance of the ODIHR to train the police on hate crimes in 2006 and presented the training of the police as a success at different international fora.

3. In addition, special security situations can result in an increased policy response to hate crimes. The author mentions among others the example of Poland, a country seeking similar assistance for police training from the ODIHR in 2008 while preparing for the organization of the 2012 European Football Championship.

4. The role of civil society organizations in combating hate crimes. Supplementing the commonly emphasized argument that data collected by CSOs must be handled cautiously since they aim at advocacy and their methodology may not be sound, she emphasizes that without the activities of CSOs the problem of hate crimes may still not be considered a priority and many victims would be left unprotected. ${ }^{7}$

In addition, official figures include the reported hate crimes, and frequently they do not take into consideration underreporting. Regarding international organizations, the author points out that those with field presence in the affected countries can be more effective and a meaningful change can be achieved only through a joint action by all different stakeholders.

Junuzovic drew very important conclusions.

'International organizations need to continue to bring the issue of hate crime to the forefront to work with governments; continuous relationships and trust between international organizations and authorities need to be fostered; synergies among international organizations are also of crucial importance as well as their aligned and unified approach to addressing hate crimes, and civil society organizations need to be strengthened in their role and further supported to continue their work. ${ }^{8}$

Finally, she points out that international organizations should invest more capacity in the follow-up of accomplished projects, and the evaluation of the real results of their action in order to improve their efficiency in addressing challenges related to implementation. This could be facilitated by consultations with local CSOs in order to review whether in any country implementation was just a "tick off" exercise.

General conceptual and philosophical issues were raised related to the phenomenon of hate crimes in the context of international institutions and human rights by Thomas Brudholm. ${ }^{9}$ The author raises theoretical questions on the interpretation of hate crimes as violations of human rights but this approach is determined by a pragmatic perspective. He discusses two possible

\footnotetext{
${ }^{7}$ Several members of the Lendület research group which the author of the present review is affiliated with, has contributed to the Working Group Against Hate Crimes. The Working Group is a coalition of civil society organizations established in 2012. It strives for the representation of the interests of victims of hate crimes in Hungary. Through her work within the Working Group, the author has gained direct experiences that are underpinning the argument of Junuzovic, namely that the work of CSOs is essential for the enforcement of decisions and recommendations issued by international organizations. These observations are useful tools of domestic advocacy, and in return their enforcement in practice requires the lobbying efforts of CSOs. For instance, recommendations of international organizations tend to be very abstract in their terms, and the details needed for the implementation in practice are frequently subject of negotiations between CSOs and national authorities.
}

${ }^{8}$ Junuzovic (2019) 271.

${ }^{9}$ Brudholm (2016) 31-48. 
major concepts regularly referring to the operation and jurisdiction of international human rights review mechanisms and primarily the European Court of Human Rights. The in-depth argumentation is preceded by an introduction of the notion of hate crimes as understood in legal terms. The author briefly summarizes the elements of hate crimes, distinguishes them from hate speech and international crimes, such as crimes against humanity and genocide. Whilst considering the potential discussion of hate crimes on equal footing with international crimes, he poses a significant question: would it trivialize the extreme horrors of mass murder? After discussing similar rather philosophical questions, Brudholm accurately points out that the distinction is clear legally speaking, the contextual elements, the widespread and systematic attack on the civilian population is a precondition of qualifying crimes as crimes against humanity. ${ }^{10}$

In the substantive arguments, the author discusses two major conceptions: the powerregulative and the dignitarian concept. The traditional view of power-regulative conception has been extended to the recognition of positive obligations of the state to provide efficient protection and remedy to the victims of attacks committed by non-state actors, individuals. This brings into the picture of the human rights system also violent attacks committed by private persons. Under this concept, the perpetrator of the human rights violations would not be the perpetrator of the hate crime itself, as human rights can be violated only by the state under this concept, and the central question would become the responsibility of the state instead of the identity of the perpetrators. An international review mechanisms would find a hate crime case admissible not due to the nature or severity of the hate crime itself, if committed by a private individual, but due to the failure of state authorities to take the necessary measures in order to prevent, investigate or punish the perpetrator of the crime.

Dignitarians, opposed to the power-regulative concept, maintain that the human rights perspective should not be limited to the relationship between the state and the individuals. Human rights violations are characterized by their universality and pre-institution nature and the respect of human rights creates duties not only on state authorities but also on private actors. ${ }^{11}$ The author, in his deliberation, expresses his preferences to the power-regulative concept and outlines his argument against the endorsement of general claims that hate crime itself should be considered a human rights violation. In his view, the power-regulative concept more accurately complies with the admissibility criteria system of existing human rights mechanisms of accountability. He approves the dignitarian conception theoretically but claims that it is "misleading" in a practical sense, since it constructs human rights violations which are inadmissible within the system of international review mechanisms. He sees human rights not as ethical or philosophical ideas, but as tools, "weapons" of the protection of individuals against the state in practice, and instruments of this goal need to be kept "sharp and focused". ${ }^{12}$ I entirely share the pragmatic opinion of the author. However, it might be worth to emphasize that his argumentation obviously applies to hate crimes which are committed by private individuals, since there is no need for this kind of deliberation in cases where the perpetrators are representatives of state agencies.

\footnotetext{
${ }^{10}$ Brudholm (2016) 36.

${ }^{11}$ Brudholm (2016) 38-40.

${ }^{12}$ Brudholm (2016) 41-44.
} 


\section{NARROWER PERSPECTIVE: SPECIFIC PROBLEMS RELATED TO THE RECORDING OF HATE CRIMES}

Certain authors, instead providing an overall assessment of international regulations and action in a general manner, turn their focus to a particular aspect of the international responses to hate crimes, conceptual issues with regard to the international interpretation of the notion of hate crime, a specific problem in practice or to the perspective of a specific protected group. Jennifer Schweppe, Amanda Haynes and Emma Marie MacIntosh have discussed the enforcement of international obligations of states to officially record hate crimes. They briefly summarizing the international obligations deriving from declarations issued by the OSCE Member States, the EU Framework Decision on Racism and Xenophobia or the Victims' Directive, then go into details about the challenges and natural limits of official reporting, and then demonstrate the importance of third party hate crime monitoring by local CSOs. The analysis is based on in-depth interviews conducted with representatives of CSOs in Ireland. The authors present how their monitoring system "(a) provide a means of reporting hate crime; (b) provide minority communities a means of reporting hate crime; (c) serve as a comparator to potentially unrepresentative official statistics where these are collected; (d) provide an evidence base for legislative change; and (e) provide a platform to affirm victims" naming of their experiences as hate crimes. ${ }^{13}$ Among their conclusions, the authors articulate a proposal to international organizations, that these organizations should, financially support these monitoring processes due to high significance of third party hate crime monitoring of CSOs. This would enable CSOs to continue uncovering the hidden figures of hate crimes.

Eszter Kirs, like Junuzovic, challenged the efficiency of an international review mechanism, namely the Universal Period Review related to hate crimes in a brief article. ${ }^{14}$ It was prepared from the perspective of Hungarian CSOs who are member organizations to the coalition Working Group Against Hate Crimes ${ }^{15}$. The main concern outlined in the article was related to the abstract language of the recommendations made under the UPR which do not address in sufficient details and pragmatism the major issues related to the efficient prosecution of hate crimes in the state under review. The article mentioned the lack of proper follow-up activities connected to the UPR recommendations and brought to the attention of the reader the role of CSOs in advocating for their implementation.

The core issue and focus of the paper authored by Schweppe, Haynes and MacIntosh is the central issue of a chapter of the Schweppe-Walters compilation authored by Michael Wine. ${ }^{16}$ The author opted for a different approach to the subject matter of data collection and the relevant impact of international organizations and does not focus on any specific state's practice but demonstrates the systematic problem of the lack of accurate recording and collection of data

\footnotetext{
${ }^{13}$ Schweppe, Haynes and MacIntosh (2018)

Interview based research findings on Ireland's compliance with relevant international legal obligations were pub-

lished the authors in the following preceding and briefer book chapter:

Haynes and Schweppe (2016) 157-73.

${ }^{14}$ Kirs (2018).

${ }^{15}$ http://www.gyuloletellen.hu/about-us.

${ }^{16}$ Wine (2016) 213-32.
} 
keeping the regional, more specifically the European perspective. He presents the general normative framework adopted under the auspices of three European inter-governmental organizations: the European Union, the Council of Europe and the Organization for Security and Cooperation in Europe; identifies the legal roots of the state obligation to accurately collect data on hate crimes and then points out evidences for the fact that states fail to fully comply with this obligation. He briefly introduces how European policy makers recognized that the increase of hate crime incidents is resulted by economic constraints, mass migration, and the easy dissemination of hate propaganda through the internet, and this might endanger peace and stability in the region. At the same time, he draws the attention to the fact that at the level of national political decisionmakers, the lack of accurate data collection on hate crimes demonstrates the lack of genuine political will to address this dangerous social phenomenon. This is one of the reasons why international organizations encourage civil society organizations to collect and report on data. ${ }^{17}$

Wine discusses the survey-based research activities of the EU Fundamental Rights Agency, the data collection efforts of the OSCE Office of Democratic Institutions and Human Rights and the reports issued by the CoE European Commission against Racism and Intolerance. All of the above research findings and reports confirmed that the normative framework, adopted in these regional organizations prescribing the obligation of states to efficiently address bias motivated crimes and to maintain a reliable and accurate data collection system, is not enforced in the practice of a significant number of European states. ${ }^{18}$ Therefore, targeted measures have been taken by the inter-governmental organizations in order to tackle the problem. Obviously, low number of registered hate crime cases can be the consequence of the lack of trust of victims towards the authorities and as a result, no report filed about the incidents; inefficient investigation of hate crimes or their inadequate qualification, due to the lack of consideration to the bias motivation behind the attack. The author finishes by presenting various projects aimed at the training of legal practitioners, conferences and workshops that have been dedicated to address the root causes of the problem, the lack of necessary knowledge and skills of legal practitioners, including police, that can result in lacking focus on bias motivation behind the criminal conduct and latency. Wine concludes with a pessimistic tone

\begin{abstract}
'Although European police and prosecutors now have the legal tools and the incentive to record hate crime as racist, the issue remains for many that everyday violent racism is usually dealt with as violent crime only, if it is reported at all. ${ }^{19}$
\end{abstract}

Another chapter of the Schweppe-Walters compilation authored by Jon Garland and Corine Funnell $^{20}$ similarly introduces FRA and ODIHR reports on the problems related to the recording of hate crimes by national stakeholders. However, this paper has a comparative perspective and discusses the differing legislation and practice given in different jurisdictions. A primary focus is on the legal definition of hate crime in certain selected countries, such as Sweden, the United Kingdom, Germany, Canada or New South Wales, Australia. ${ }^{21}$ The various

\footnotetext{
${ }^{17}$ Wine (2016) 214-15.

${ }^{18}$ Wine (2016) 220-24.

${ }^{19}$ Wine (2016) 228.

${ }^{20}$ Garland and Funnell (2016) 15-30.

${ }^{21}$ Garland and Funnell (2016) 20-26.
} 
legislative solutions demonstrate how significant differences need to be faced at the international level. The authors appear to come to a negative judgment over the achievement of international organizations while facing these challenges and striving for harmonization and the implementation of the European norms. They found that these organizations did not have considerable influence on whether states actively seek to address hate crimes. They articulated strong critics on the "top-down" human rights-based approach of international institutions, found that international programs have failed to tackle the problems, and suggested that grassroots initiatives should be encouraged based on a "bottom-up" approach. ${ }^{22}$ However, specific pragmatic proposals are painfully missing from the book chapter.

\section{NARROWER PERSPECTIVE: THE INTEREST OF PROTECTED GROUPS}

Academic papers focusing on a specific victim group of hate crimes, tend to cover a broader scope of problems related to the protection of the relevant minority group. This is the approach of Axelle Reiter in her paper $^{23}$ on the protection of Roma people against violence and discrimination. She touches upon various issues, such as forced sterilization of Roma women, segregation in education or the dissolution of extremist groups. She discusses discriminative practices targeting Roma people from the point of view of the application of the European Convention on Human Rights. She argues, regarding bias motivated violent attacks committed against Roma victims, that the European Court of Human Rights has developed innovative interpretative methods to provide more efficient protection to the ethnic group. The first part of the relevant chapter of the paper has the primary emphasis on police brutality, and in a rather unstructured style. ${ }^{24}$ More structured and in-depth summary of the case law of the ECtHR is to be seen in other sources, such as research reports published by international organizations.

Jasmina Mackic claims, opposing Reiter's view that the European Court of Human Rights has considerably facilitated the enhanced protection of the Roma minority group, that the Court could have played a much more significant role in combatting hate crimes at the European level. ${ }^{25}$ In her view,

'the ECtHR may also play a valuable role as an international body in the process of condemning hate crime in Europe, particularly in those $\mathrm{CoE}$ countries where there is a lack of adequate hate crime legislation, or where the domestic authorities fail to apply existing hate crime laws in practice. ${ }^{26}$

The author's argumentation seems to be determined by the perspective that the Court should not be seen solely as a judicial body but rather as an international institution which can have a valuable impact on state practice and policies. This approach is legitimate in theory but requires a cautious assessment of the practice of the Court which respects its fundamentally judicial mandate and independence that are essential also for maintaining its credibility. Mackic claims

\footnotetext{
${ }^{22}$ Garland and Funnell (2016) 16, 27.

${ }^{23}$ Reiter (2016) 5-24.

${ }^{24}$ Reiter (2016) 10-12.

${ }^{25}$ Mackic (2016) 233-46.

${ }^{26}$ Mackic (2016) 234.
} 
that the Court tends to be unwilling to address discriminatory aspects in violence matters by analyzing certain selected cases.

The most detailed assessment presented by the author is focused on a judgment delivered in the case of Karaahmed v Bulgaria in 2015 by the Court. The case concerned incidents arising from a demonstration by followers of "Ataka", a political party known for its views against Islam and its adherents. The demonstration was held in front of the Banya Bashi Mosque in Sofia during Friday prayers. The demonstrators were carrying flags featuring slogans such as "Let's get Bulgaria back;" shouting insults at the worshippers such as "Turkish stooges", "filthy terrorists", some of them were cutting a Turkish fez with a pocket knife while saying "Can you hear me? We shall now show you what will happen to each one of you!" and setting fire to prayer rugs. The bias motivation behind the acts of the demonstrators was obvious. The Court did not apply Article 3 finding that the required threshold was not met. Instead, it found the violation of Article 9 of the Convention due to the fact that the Bulgarian state authorities failed to comply with their positive obligation to protect the members of the religious group. The primary subject of Mackic's criticism is that the Court decided not to apply Article 14 based on the argument that the relevant discriminatory circumstances were already examined under Article 9. ${ }^{27}$ The author claims that by this decision the Court disregarded the anti-Islam overtone of the incident. However, she fails to mention that the Court did discuss the bias motivation behind the attacks in its reasoning, and that high-level political statements were referred to. The Court accepted that the condemnation of the demonstrators' actions by both the President and the Parliament ${ }^{28}$ expressed disapproval and determination to ensure that the incident remained a one-off. ${ }^{29}$ The $^{2}$ author could have applied a more nuanced approach by considering all the circumstances that were weighed by the Court which is mandated with the assessment of state responsibility, taking into consideration the reaction of all state agencies to the incident. The author seems to have made a far-fetched judgement about the Court's action by qualifying the judicial decision "incomprehensible" 30 without considering all of its relevant elements.

Acknowledging the Court's ability to have a significant impact on the regulative or policy agendas of national legislatures and executive bodies, Mackic argues that the Court could use its agenda-setting power by "condemn[ing] discriminatory violence committed towards members of minorities in each case before it". ${ }^{31}$ In its scope it seems to be a broad suggestion without respect to the inherent nature of the Court namely that it is supposed to be assessing each case based on the specific circumstances outlined in the submissions of the parties, and such generalized proposals do not comply with the rules of its operation.

\footnotetext{
${ }^{27}$ Karaahmed $v$ Bulgaria App no 30587/13 (ECtHR, 24 February 2015) 112.

${ }^{28}$ The Parliament adopted a declaration which reads as follows: "Members of Parliament categorically condemn the aggression of the political party 'Ataka' of 20 May 2011 against worshippers in the centre of the capital. It is particularly scandalous that this was done on a Friday, a holy day for Muslims, at the time of their obligatory prayer. With those actions, that party isolated itself from democratic society in Bulgaria. The conduct of that party is deeply alien to the Bulgarian people, to its religious and ethnic tolerance. We express our profound disquiet at the attempts to undermine the ethnic peace and to stir up religious tensions between Bulgarian citizens." Karaahmed v Bulgaria App no 30587/13 (ECtHR, 24 February 2015) 27.

${ }^{29}$ Karaahmed $v$ Bulgaria App no 30587/13 (ECtHR, 24 February 2015) 109.

${ }^{30}$ Mackic (2016) 237.

${ }^{31}$ Mackic (2016) 240.
} 
The author draws attention to the fact that discriminatory violence has a large impact both on the direct victim (encroaching not merely upon the physical being, but also on the very core of the identity), the victim's community and the larger society. Therefore, she claims the Court should

'through a greater elaboration on discriminatory violence complaints, not just show attentiveness towards the potential individual victims, but may even emphasize the generality of this problem. ${ }^{32}$

Without claiming that the Court could not do more for the enhanced protection of victim communities, I need to point out that the author seems to have overlooked concepts and arguments appearing in the Court's judgments that emphasize the severe impact of hate crimes both on the victim, the target community and the society as a whole that require special measures, ${ }^{33}$ arguments that contribute to the advocacy for the enhanced protection of minorities.

\section{CONCLUSIONS}

The available literature on the international normative and institutional framework relevant to hate crimes is far from complete considering the complexity of the subject matter. Both theoretical and pragmatic issues have been discussed by academic authors, such as the challenges coming with the obligation of states to record hate crimes or to conduct efficient investigation,

\footnotetext{
${ }^{32}$ Mackic (2016) 242-43.

${ }^{33}$ See for instance: "The Court reiterates that when investigating violent incidents, State authorities have the additional duty to take all reasonable steps to unmask any racist motive and to establish whether or not ethnic hatred or prejudice may have played a role in the events. Admittedly, proving racial motivation will often be extremely difficult in practice. The respondent State's obligation to investigate possible racist overtones to a violent act is an obligation to use best endeavours and is not absolute; the authorities must do what is reasonable in the circumstances of the case. [...] The Court considers it unacceptable that, being aware that the event at issue was most probably induced by ethnic hatred, the police allowed the investigation to last for more than seven years without taking any serious action with a view to identifying or prosecuting the perpetrators"

Secic v. Croatia App no 40116/02 (ECtHR, 31 May 2007) 66, 69.“

Treating religiously motivated violence and brutality on an equal footing with cases that have no such overtones would be turning a blind eye to the specific nature of acts that are particularly destructive of fundamental rights. A failure to make a distinction in the way in which situations that are essentially different are handled may constitute unjustified treatment irreconcilable with Article 14 of the Convention."

Begheluri and others v. Georgia App no 28490/02 (ECtHR, 7 October 2014) 173.“

The Court further considers it unacceptable that, being aware that the attacks in question had most probably been motivated by religious hatred, the respondent State's authorities allowed the investigation to last for many years without taking adequate action with a view to identifying or prosecuting the perpetrators [...] it is noted that the police themselves referred to the applicant's well-known religious beliefs, as well as his 'strange appearance', and apparently attached particular significance to "the fact" that most of the attacks against him had been reported before or after a major orthodox religious holiday, which incidents the applicant subsequently publicised through the mass media in the context of his own religious affiliation. The Court considers, once again, that such views alone imply that the police had serious doubts, related to the applicant's religion, as to whether he was a genuine victim, notwithstanding that there was no evidence to warrant doubts of this sort. It follows that even though the authorities had explored several leads proposed by the applicant concerning the underlying motivation of his attackers these steps amounted to little more than a pro forma investigation."
}

Milanovic v. Serbia App no 44614/07 (ECtHR, 14 December 2010) 99-100. 
the limits of the potential impact of international review mechanisms, or the aims and content of resolutions adopted by international institutions and judgments delivered by the European Court of Human Rights. However, a wide range of practical and conceptual issues related to the existing international standards and the efficiency of international review mechanisms remain to be discussed in the academic sphere.

\section{LITERATURE}

Brudholm, T., 'Conceptualizing hatred globally: is hate crime a human rights violation?' in Schweppe, J., Walters, M. A. (eds) The Globalization of Hate (OUP 2016) 31-48.

Directorate-General for Research (n.d), 'European Union Anti-Discrimination Policy - From equal opportunities between women and men to combatting racism, Public Liberties Series, LIBE 102 EN' <http://www.europarl.europa.eu/workingpapers/libe/102/text1_en.htm.> accessed 15 December 2020.

Garland, J., Funnell, C., 'Defining hate crime internationally: issues and conundrums' in Schweppe, J., Walters, M. A. (eds) The Globalization of Hate (OUP 2016) 15-30.

Givens, T. E., Case, R. E., Legislating equality - The Politics of Antidiscrimination Policy in Europe (OUP 2014).

Haynes, A., Schweppe, J., 'Internationalizing hate crime and the problem of the intractable state: the case of Ireland' in Schweppe, J., Walters, M. A. (eds) The Globalization of Hate (OUP 2016) 157-73.

Iganski, P., 'Legislating morality, and competing "rights": legal instruments against racism and antisemitism in the European Union' Journal of Ethnic and Migration Studies (1999) 25 509-16.

Junuzovic A., 'To what extent have international organizations triggered responses/actions at national levels to address hate crime?', (2019) Crime, Law and Social Change <https://doi.org/10.1007/s10611019-09820-1> accessed 15 December 2020.

Kirs, E., 'A brief reflection on the impact of the Universal Periodic Review on the efficient investigation of hate crimes in Hungary', (2018) 3/3 Corvinus Journal of International Affairs <http://journals.lib.unicorvinus.hu/index.php/cojourn/article/view/275> accessed 15 December 2020.

Mackic, J., 'The European Court of Human Rights and discriminatory violence complaints' in Schweppe, J., and Walters, M. A. (eds) The Globalization of Hate (OUP 2016) 233-46.

Reiter, A., 'Protection against Violence and Discrimination: The Case of Roma Victims in Member States of the Council of Europe' Temida 19/1 (2016) <http://www.doiserbia.nb.rs/img/doi/1450-6637/2016/ 1450-66371601005R.pdf> accessed 15 December 2020.

Schweppe, J., Haynes, A., MacIntosh, E. M., 'What is Measured Matters: The Value of Third Party Hate Crime Monitoring', European Journal on Criminal Policy and Research (2018) <https://doi.org/10.1007/ s10610-018-9403-4> accessed 15 December 2020.

Wine, M., 'National monitoring of hate crime in Europe: the case for a European level policy' in Schweppe, J., and Walters, M. A. (eds) The Globalization of Hate (OUP 2016) 213-32.

Open Access. This is an open-access article distributed under the terms of the Creative Commons Attribution 4.0 International License (https://creativecommons.org/licenses/by/4.0/), which permits unrestricted use, distribution, and reproduction in any medium, provided the original author and source are credited, a link to the CC License is provided, and changes - if any - are indicated. (SID_1) 